\title{
APLIKASI WEB PORTAL MANAJEMEN INFORMATIKA BERBASIS WEBSITE DENGAN MENGGUNAKAN FRAMEWORK CODEIGNITER DAN MYSQL PADA UNIVERSITAS CATUR INSAN CENDEKIA
}

\author{
Wahyudi Fajar Ramadhan ${ }^{1}$, Wiwiek Nurkomala ${ }^{2}$, Chairun Nas $^{3}$ \\ Universitas CIC Cirebon \\ Jl. Kesambi 202, Kota Cirebon, Jawa Barat. Telp: (0231) 220350 \\ Email : wahyudifajar844@gmail.com ${ }^{1}$ wiwiek.nurkomala.dewi@cic.ac.id ${ }^{2}$,chairunnas.asleb@gmail.com ${ }^{3}$
}

\begin{abstract}
ABSTRAK
Universitas CIC merupakan institusi pendidikan di bawah naungan yayasan catur insan cendekia (CIC) yang memiliki beberapa prodi salah satunya Program Study Manajemen Informatika. Saat ini prodi Manajemen Informatika belum memiliki website portal resmi untuk menyebarkan informasi.Tujuan Penelitian ini bertujuan untuk membuat Aplikasi Portal Manajemen Informatika Untuk Menyebarkan informasi Aplikasi website ini didalamnya mengelola Data Master (Data Dosen MI, Data Mahasiswa, Data Alumni MI, Data Buku Tamu, Data Artikel, Data Kegiatan, Data Agenda, Data Mahasiswa Berprestasi, Data Katalog, Data Informasi, Data Testimoni), Data Statistik, Data Media (Data Galeri dan Data Video), dan lain-lain, dengan menggunakan metode waterfal. Hasil dengan adanya Aplikasi website portal ini dapat membantu Prodi Manajemen Informatika dalam melakukan promosi dan penyampaian informasi kepada masyarakat agar lebih cepat.
\end{abstract}

Kata kunci: portal, php, informasi, web server, codeigniter.

\begin{abstract}
CIC University is an educational institution under the Chessman Scholar Foundation (CIC) which has several study programs, one of which is the Informatics Management Study Program. Currently the Informatics Management study program does not yet have an official portal website to disseminate information. The purpose of this study aims to create a Information Management Portal Application to disseminate information. This website application includes managing Master Data (MI Lecturer Data, Student Data, MI Alumni Data, Guest Book Data, Article Data, Activity Data, Agenda Data, Student Achievement Data. , Catalog Data, Information Data, Testimonial Data), Statistical Data, Media Data (Gallery Data and Video Data), and others, using the waterfal method. The results with this portal website application can help the Informatics Management Study Program in promoting and delivering information to the public more quickly.
\end{abstract}

Keywords: portal, php, information, web server, codeigniter.

\section{Pendahuluan}

Seiring dengan berjalannya waktu perkembangan teknologi informasi semakin pesat. Oleh karena itu semakin banyak muncul ide-ide baru dalam dunia teknologi informasi. Tak dapat dipungkiri bahwa banyak pula orang-orang yang terjun dalam dunia teknologi informasi karena dalam segi kehidupan masyarakat dan mahasiswa pasti akan terlibat akan adanya komunikasi dan informasi. Misalnya saja dalam Informasi

Aplikasi Web Portal Manajemen Informatika Berbasis Website Dengan Menggunakan Framework Codeigniter Dan Mysql Pada Universitas Catur Insan Cendekia - (Wiwiek Nurkomala, Chairun Nas, 
Aplikasi Website Portal Manajemen Informatika. Artikel yang selalu update dan menampilkan mahasiswa/mahasiswi yang berprestasi dan mendapatkan IPK tertinggi untuk motifasi mahasiswa lainnya.

Belum ada website manajemen informatika untuk media informasi yang membuat mahasiswa baru dan masyarakat kesulitan untuk mendapatkan informasi aktifitas Terbaru Tentang Manajemen Informatika yang bisa di akses melalui smartphone. ada media informasi namun belum maksimal untuk mendapatkan informasi mahasiswa dan masyarakat harus datang ke kampus untuk mendapatkan informasi. Sulitnya mencari contoh tugas akhir, proposal dan proyek MI.

Dengan adanya Aplikasi Website Portal Manajemen Infromatika maka mahasiswa baru dan mahasiwa yang sudah kuliah maupun masyarakat dapat dengan mudah mengakses dan mendapatkan informasi terbaru tentang Manajemen Informatika setiap saat. semakin canggihnya teknologi informasi juga tidak hanya disajikan dengan teks akan tetapi dapat disajikan melalui gambar dan video.

Berdasarkan latar belakang di atas maka tercetuslah ide untuk membuat Aplikasi Website Portal manajemen informatika berbasis Website menggunakan bahasa pem-rograman Framewrok CodeIgniter dan database MySQ1.

\section{KAJIAN PUSTAKA}

\subsection{Sistem Informasi}

Menurut Jeperson Hutahaean dalam bukunya yang berjudul "Konsep Sistem Informasi” (2015:10), Informasi adalah data yang diolah men-jadi bentuk yang lebih berguna dan lebih berarti bagi penerimanya.Sumber informasi adalah data. Data kenyataan yang menggambarkan suatu kejadi-ankejadian dan kesatuan nyata. Kejadian-kejadian (event) adalah kejadian yang terjadi pada saat tertentu. [1]

\subsection{Web Portal}

Menurut (Baiq Nonik. dkk, 2017). Web Portal adalah sebuah situs web yang menyediakan beragam informasi dari berbagai sumber dengan cara (format/layout) yang seragam. Setiap sumber informasi mendapat area khusus pada halaman website portal dalam menampilkan informasinya. [2]

\subsection{Web Server}

Menurut (Fhery Agustin., 2017) Untuk membangun sebuah web portal padasebuah jaringan intranet dibutuhkan aplikasi web server. Terdapat beberapa pilihan aplikasi web server yang dapat digunakan, tergantung kepadabasis pemrogramannya. Apabila sistem informasiyang akan dibangun berbasis PHP dan Mysql maka sebaiknya web server yang digunakan adalah Apache. Selain aplikasi ini bersifat open source yang artinya gratis, Apache juga dapat di andalkan [3]

\subsection{Pengertian Website}

Menurut Rohi Abdulloh dari bukunya yang berjudul "Easy \&Simple Web Programming” (2016), Website atau disingkat web, dapat diartikan sekumpulan halaman yang terdiri atas beberapa laman yang berisi informasi dalam bentuk data digital, baik berupa teks, gambar,video, audio, dan animasi lainnya yang di sediakan melalui jalur koneksi internet [4]

\subsection{Pengertian Framework CodeIgniter}

Menurut (Zulkifli Ahmad., 2018). Framework CodeIgniter adalah sekumpulan library yang diorganisasikan pada sebuah rancangan arsitektur untuk memberikan kecepatan, ketepatan, kemudahandan konsistensi di da-lam pengembangan aplikasi dari definisi tersebut". Dari definisidi atas, penulis menyimpulkan bahwa framework merupakan kumpulan library atauclass yang masing-masing memiliki fungsi tersendiri dalam mem-bangun sebuahkerangka kerja. Sebuah Framework CodeIgniter terdiri dari:

\subsubsection{Model}

Model mencakup semua proses yang terkait dengan pemanggilan struktur data baik berupa pemanggilan fungsi, input processing atau mencetak outputke dalam browser.

\subsubsection{View}

View mencakup semua proses yang terkait layout output. Bisa dibilang untuk menaruh template interface website atau aplikasi.

\subsubsection{Controller}

Controller mencakup semua proses yang terkait dengan pemanggilan databasedan kapsulisasi proses proses utama. Jadi semisal dibagian ini ada filebernama member.php, maka semua proses yang terkait dengan member akan di kapsulisasi/ dikelompokan dalam file ini. 


\subsection{Manajemen Informatika}

Manajemen Informatika Universitas Catur Insan Cendekia Cirebon terletak di Jl.kesambi no.202, Drajat, Kec. Kesambi, Kota Cirebon, Jawa Barat 45133. Manajemen Informatika Universitas Catur Insan Cendekia tersebut beroperasi setiap hari senin sampai dengan Jum'at.

\subsubsection{Struktur Organisasi}

Struktur Organisasi di Manajemen Informatika Universitas Catur Insan Cendekia Cirebon terdiri dari bagian-bagian organisasi atau instansi dalam men-jalankan kegiatan operasional untuk mencapai tujuan yang diharapkan dan di-inginkan. Struktur organisasi menggambarkan dengan jelas pemisah kegiatan pekerjaan antara yang satu dengan yang lainnya. Struktur organisasi Manajemen Informatika Universitas Catur Insan Cendekia Cirebon pada gambar 1.

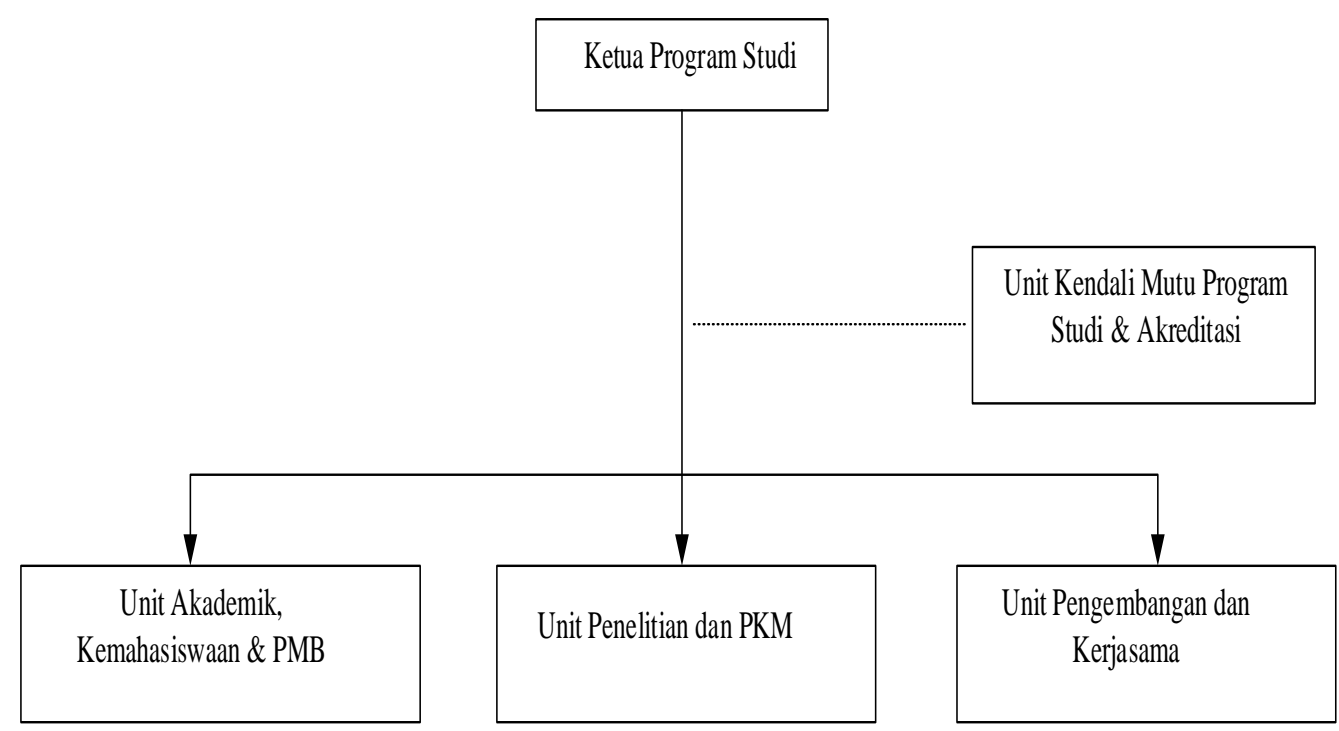

Gambar 1. Struktur Manajemen Informatika

\section{PERANCANGAN}

\subsection{Flowcmap Sistem Usulan}

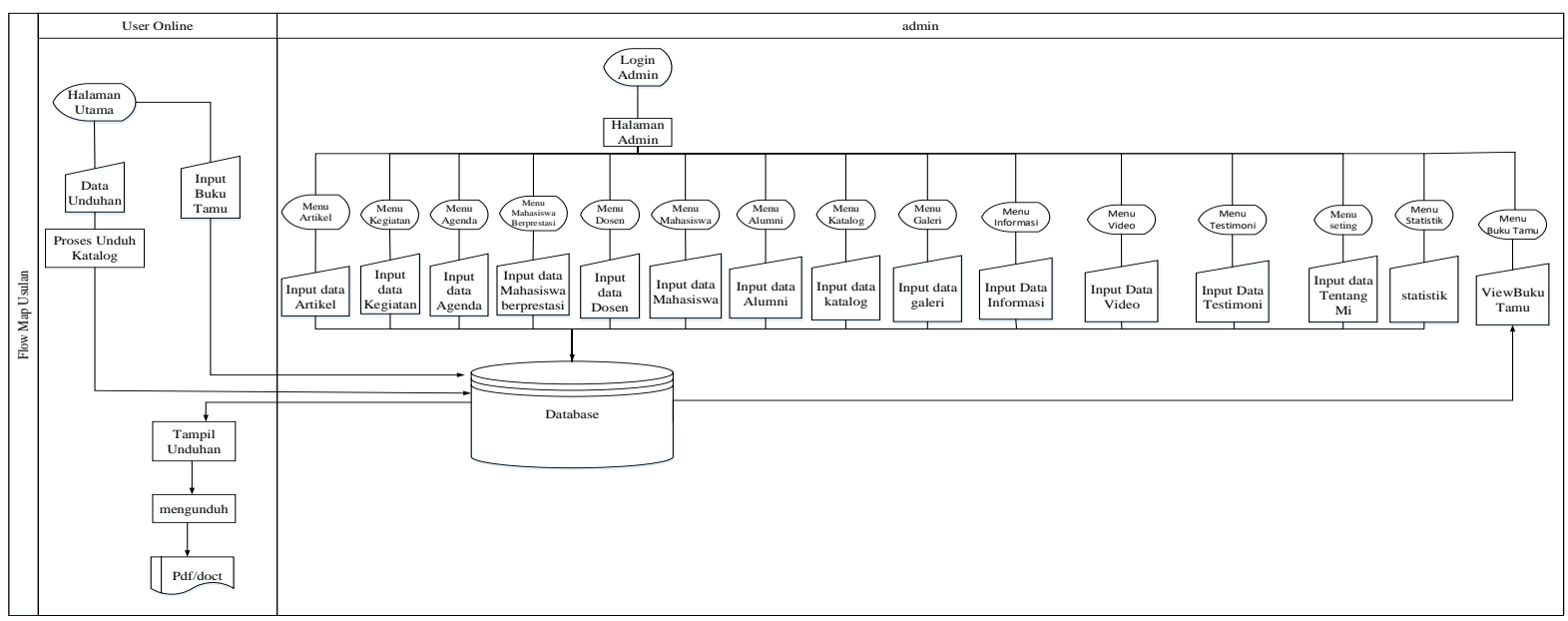

Gambar 2. Flowmap sistem usulan

Aplikasi Web Portal Manajemen Informatika Berbasis Website Dengan Menggunakan Framework Codeigniter Dan Mysql Pada Universitas Catur Insan Cendekia - (Wiwiek Nurkomala, Chairun Nas, 


\subsection{Diagram Konteks}

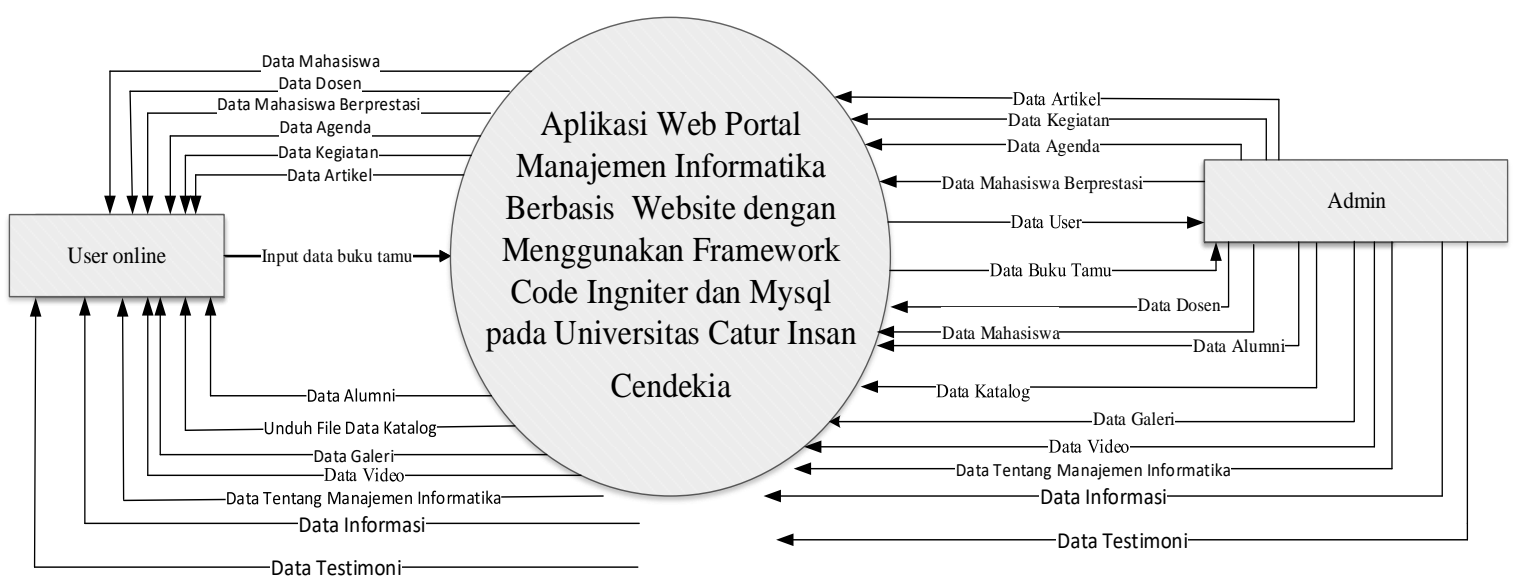

Gambar 3. Diagram Konteks

\subsection{Diagram DFD Level 0}

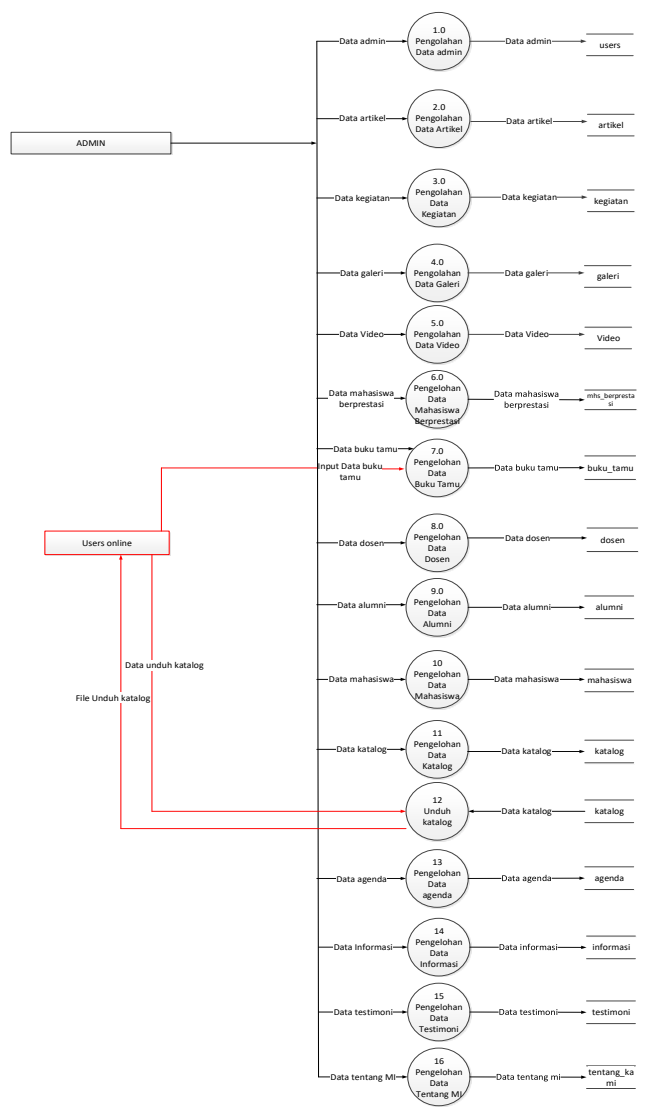

Gambar 4. DFD Level 0 


\subsection{Diagram Relasi}

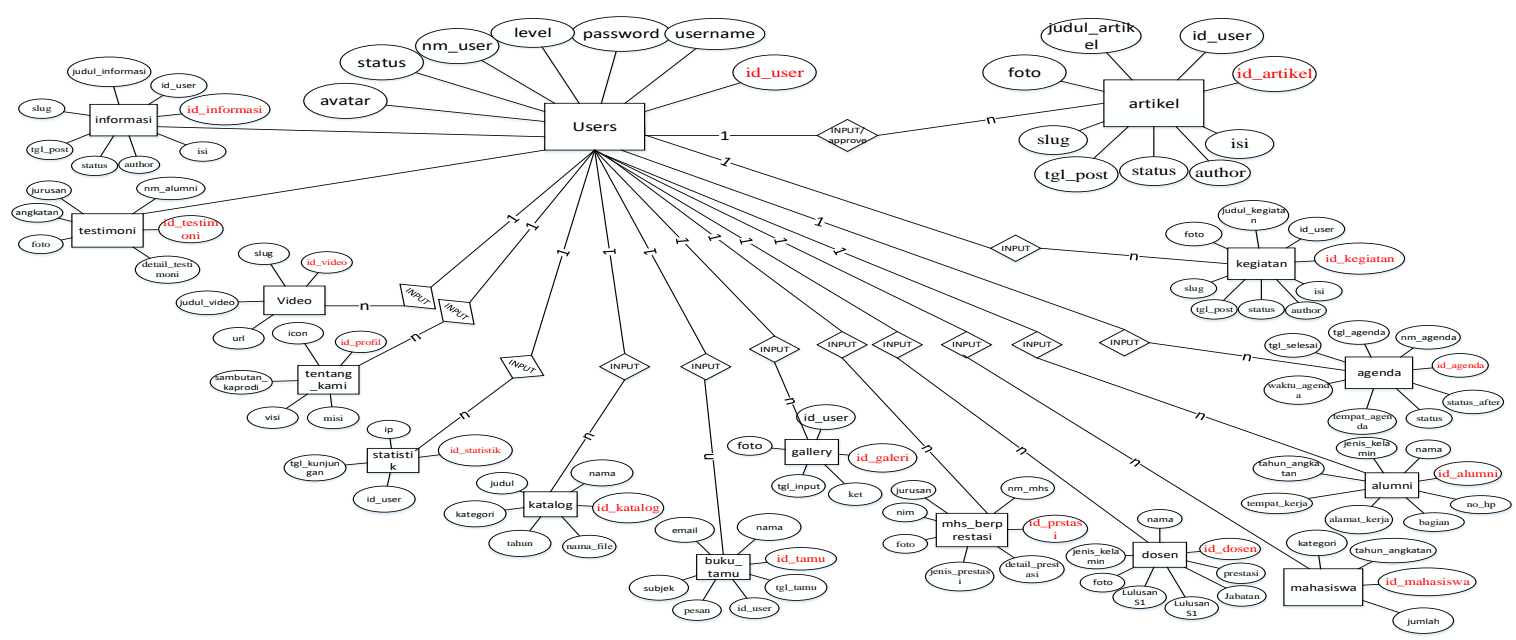

Gambar 5. Diagram Relasi ERD

\section{PEMBAHASAN}

4.1 Tampilan Halaman Web

4.1.1 Halaman Login Admin

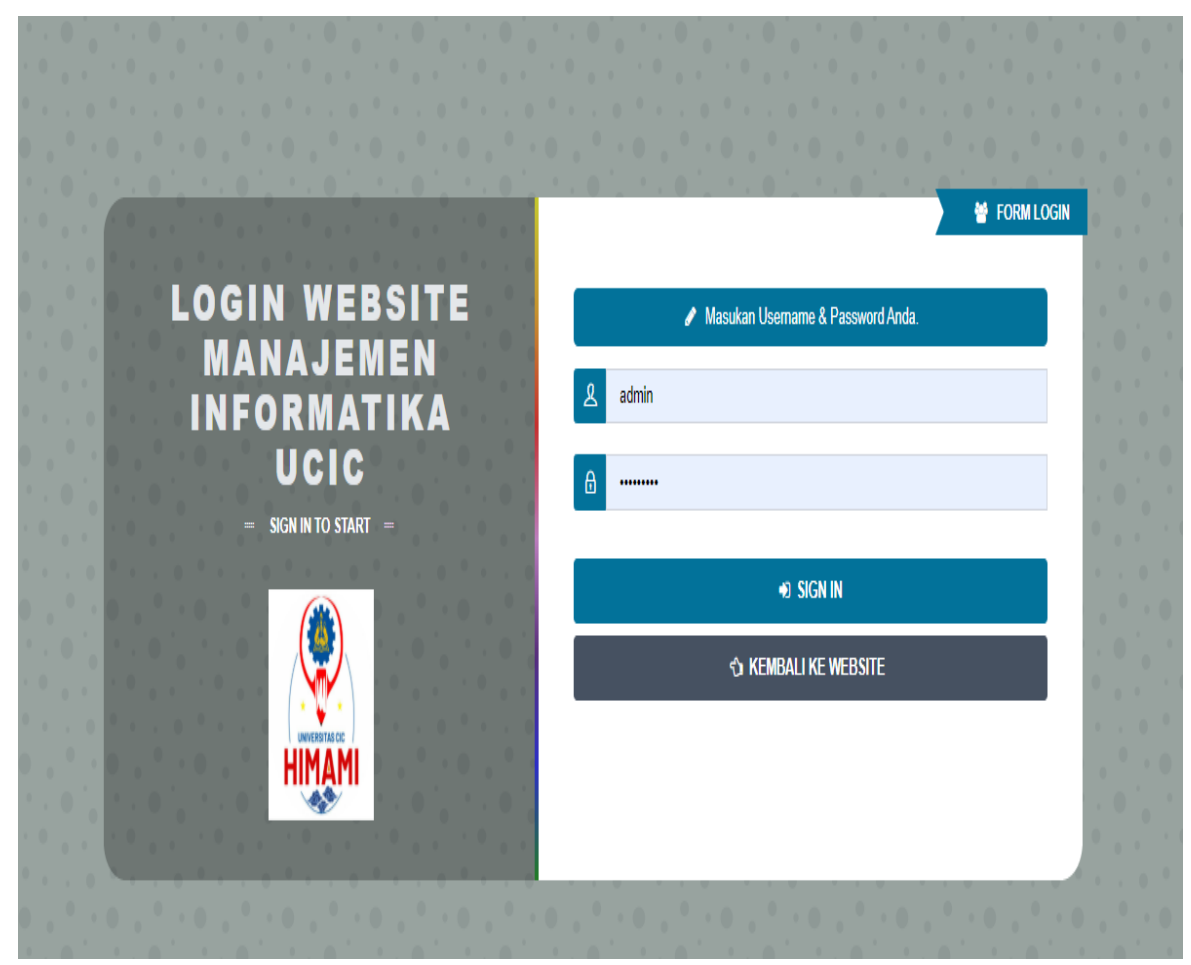

Gambar 6. Halaman Login Admin

Aplikasi Web Portal Manajemen Informatika Berbasis Website Dengan Menggunakan Framework Codeigniter Dan Mysql Pada Universitas Catur Insan Cendekia - (Wiwiek Nurkomala, Chairun Nas, 


\subsubsection{Halaman Menu Utama Admin}

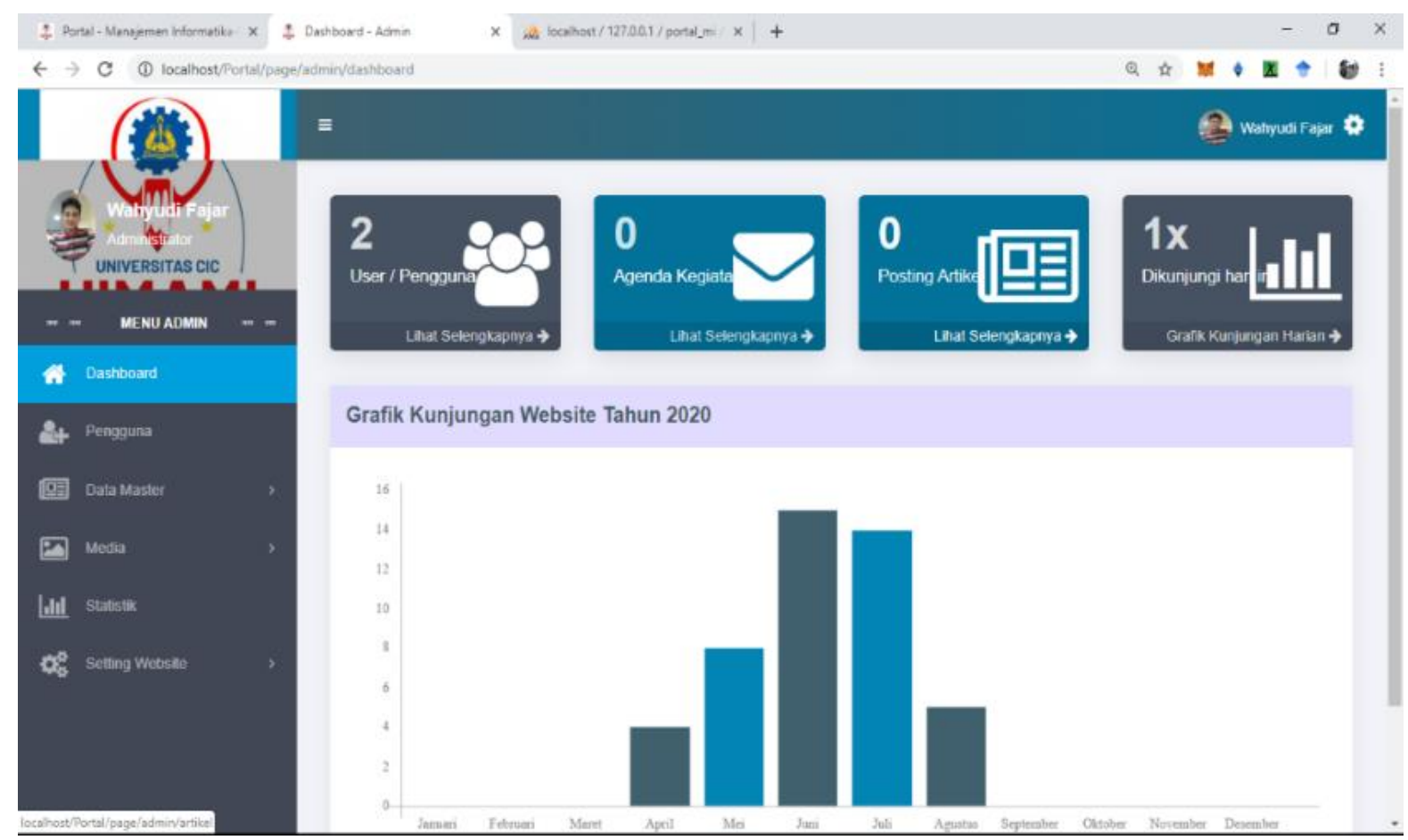

Gambar 7. Halaman Menu Utama Adminr

\subsubsection{Halaman Menu Tambah Admin}

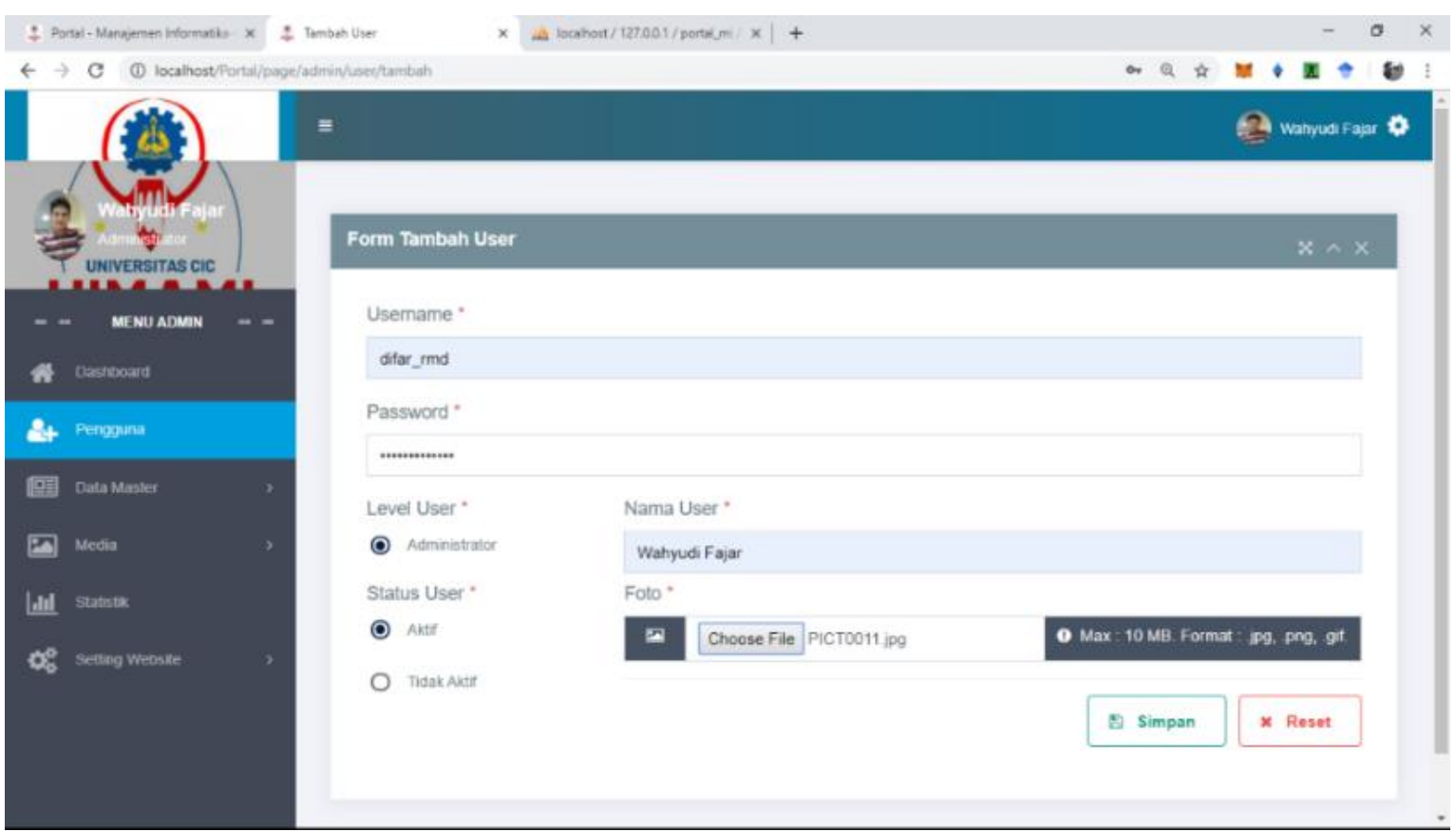

Gambar 8. Halaman Menu Tambah Admin 


\subsubsection{Halaman Menu Tambah Artikel}

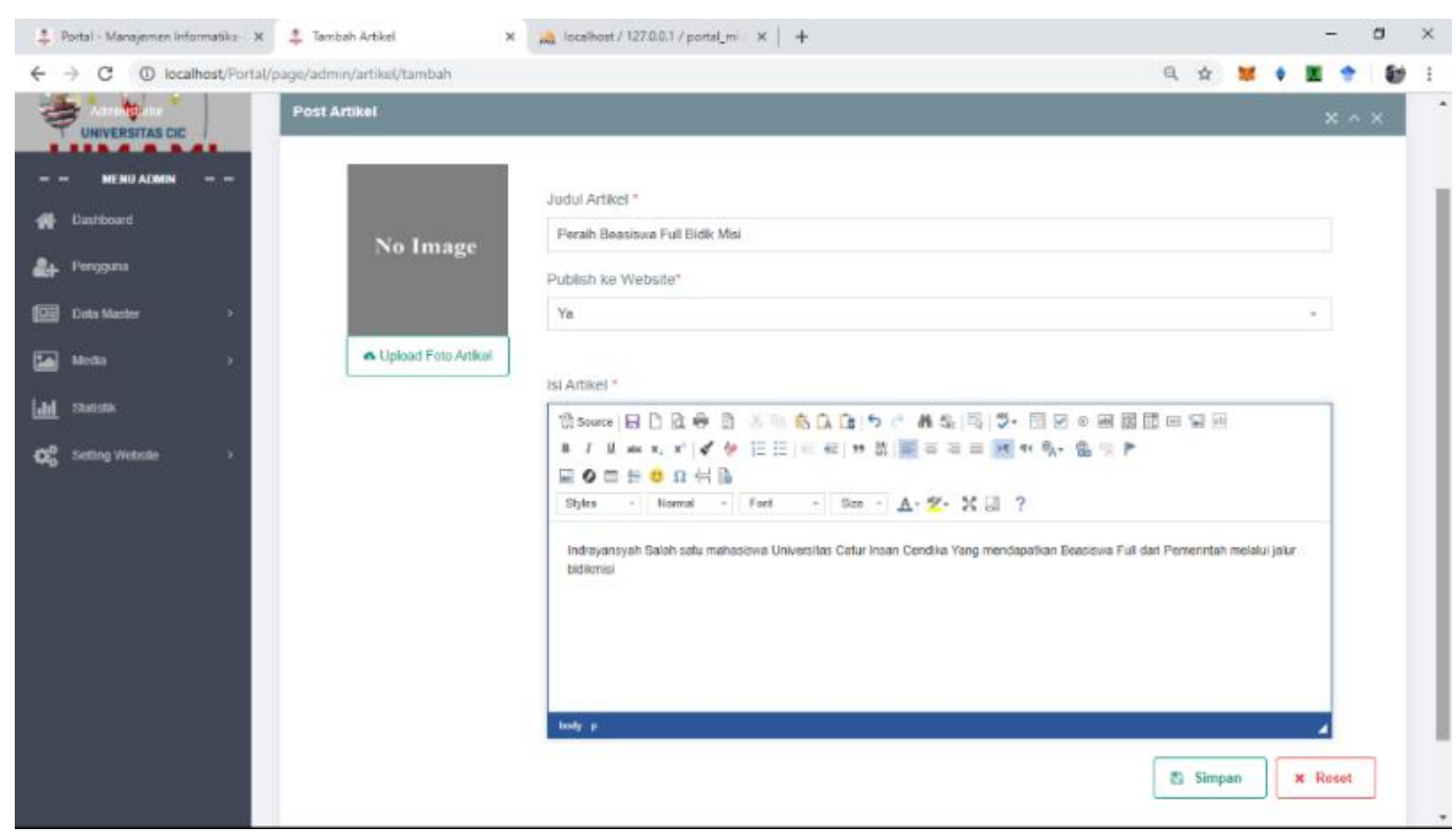

Gambar 9. Halaman Menu Tambah Artikel

\subsubsection{Halaman Menu Tambah Kegiatan}

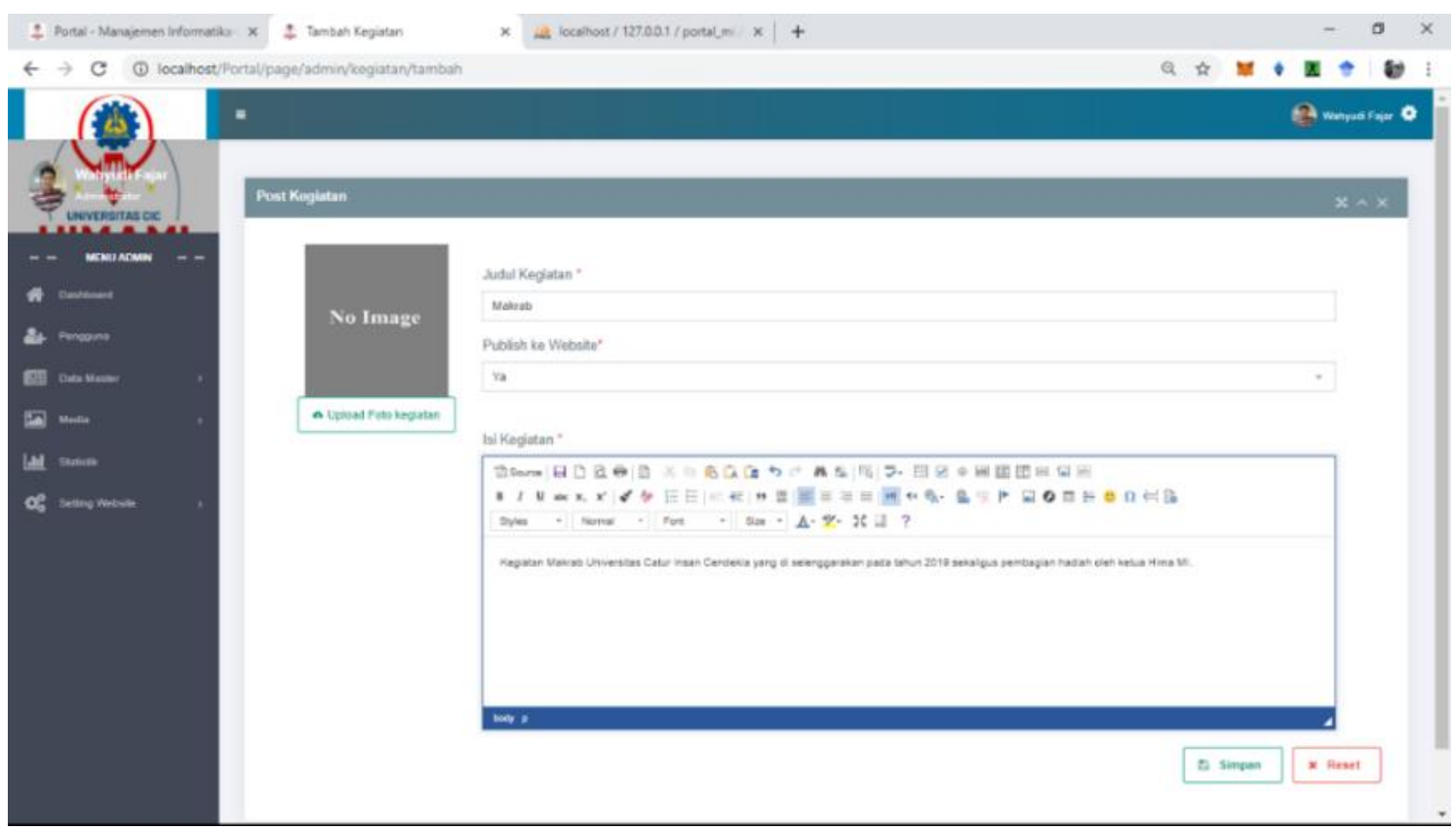

Gambar 10. Halaman Menu Tambah Kegiatan

Aplikasi Web Portal Manajemen Informatika Berbasis Website Dengan Menggunakan Framework Codeigniter Dan Mysql Pada Universitas Catur Insan Cendekia - (Wiwiek Nurkomala, Chairun Nas, 


\subsection{Halaman Output}

4.2.1 Halaman Utama User Online

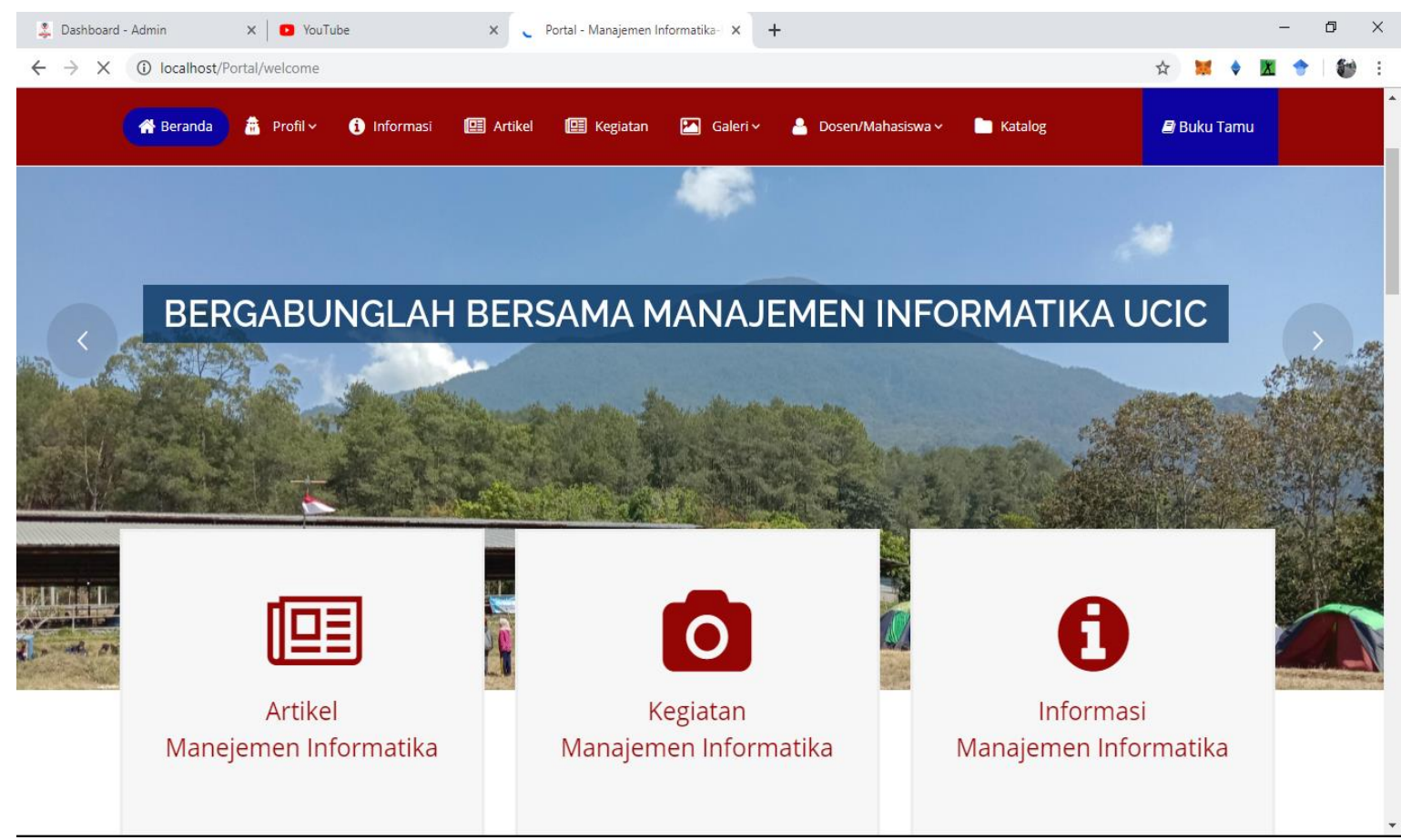

Gambar 11. Halaman Utama User Online

\subsubsection{Halaman Menu Artikel (User Online)}

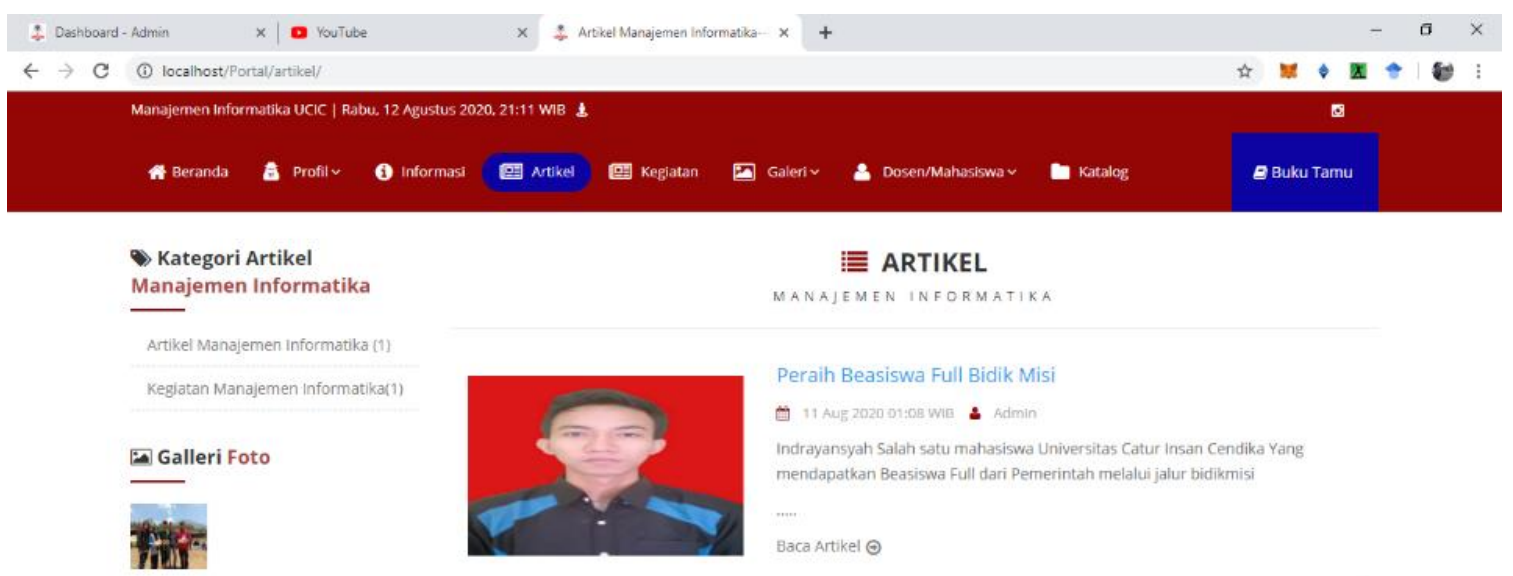

Gambar 11. Halaman Menu Artikel (User Online) 


\subsubsection{Halaman Menu Kegiatan (User Online)}
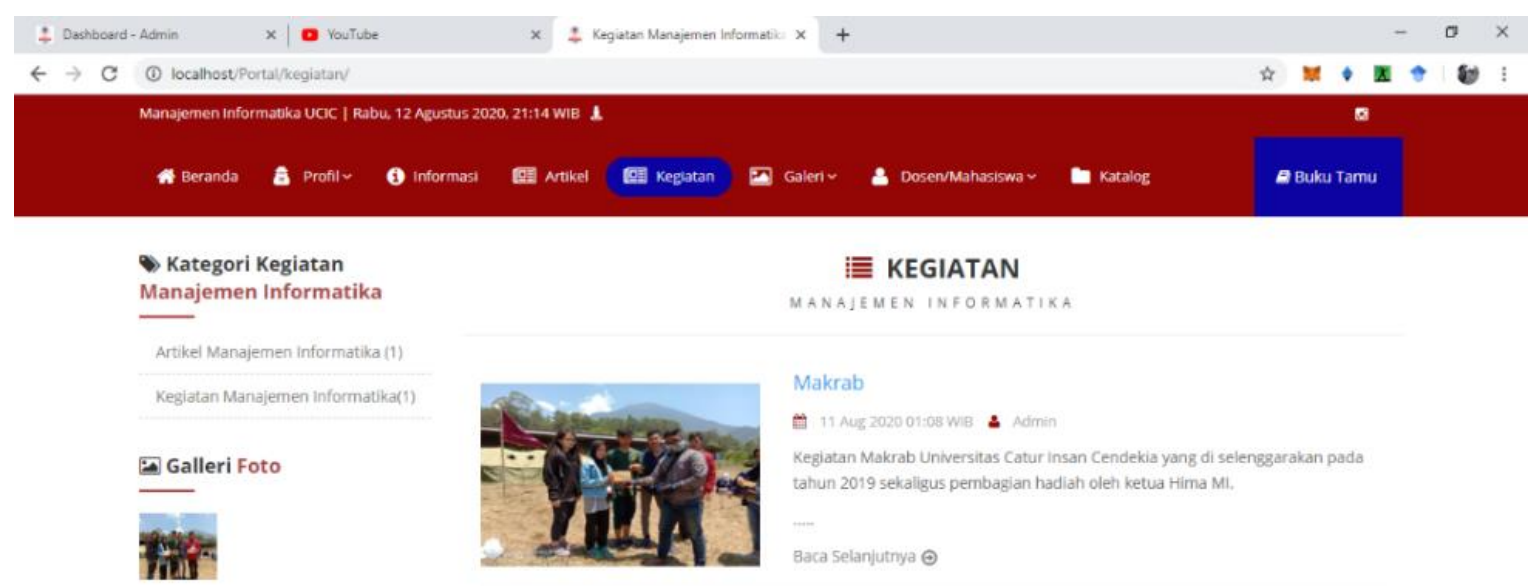

Gambar 12. Halaman Menu Kegiatan (User Online)

\subsubsection{Halaman Menu Galeri Foto}

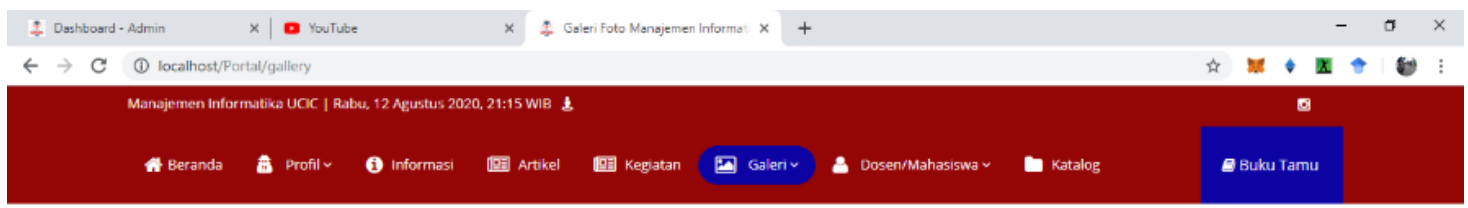

E GALERI FOTO

MANAJEMEN INFORMATIKA

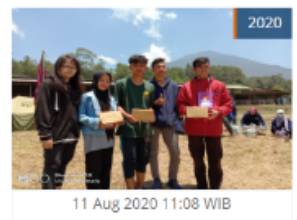

pembaglan hadlah di akhir

\section{Gambar 13. Halaman Menu Galeri Foto}

Aplikasi Web Portal Manajemen Informatika Berbasis Website Dengan Menggunakan Framework Codeigniter Dan Mysql Pada Universitas Catur Insan Cendekia - (Wiwiek Nurkomala,Chairun Nas, 


\subsubsection{Halaman Menu Video}
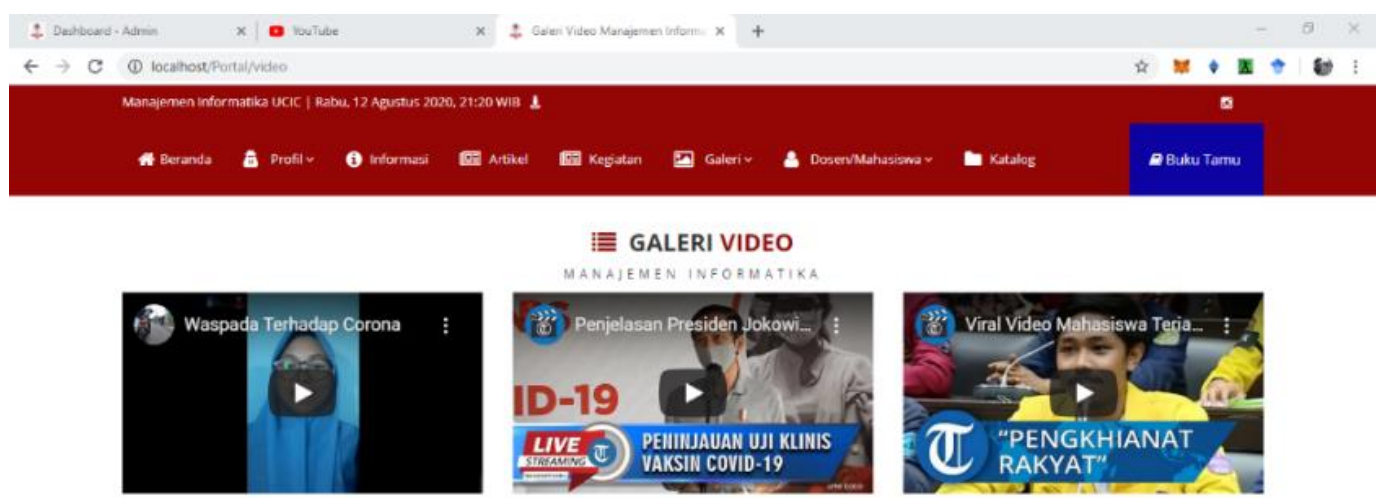

巨E GALERI VIDEO

MANAIEMEN INEOAMATIKA

Waspada Techadap Vidrus corona

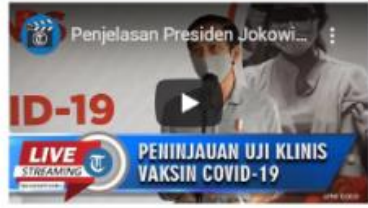

penjelasan pak jokow

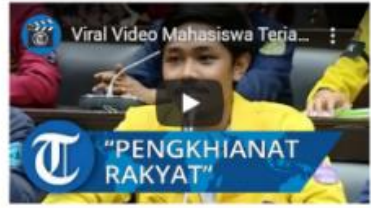

Demo Mahasiswa UI

\section{Gambar 14.. Halaman Menu Video}

\subsubsection{Halaman Menu Katalog}

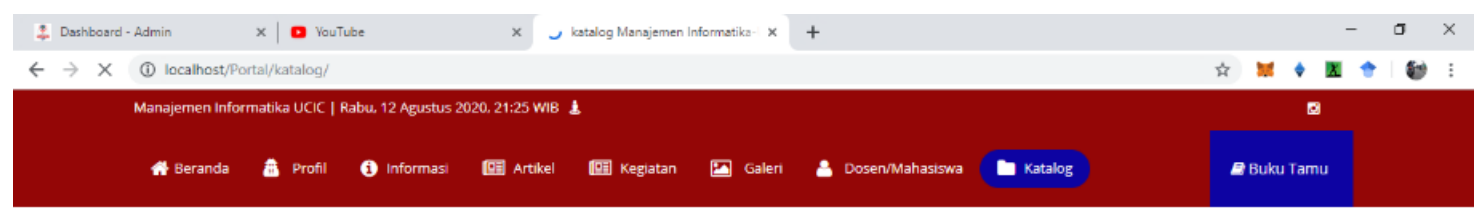

E DATA KATALOG

MANAJEMEN INFORMATIKA

\begin{tabular}{|c|c|c|c|c|}
\hline No Nama & Judul & Kategori & Tahun & Download \\
\hline wahyudi dan rahardi & Aplikasi Perpustakan Berbasis Website di Kejaksaan Cirebon & Proyek & 2020 & \pm Download \\
\hline adit dan faisal & Aplikasi cuti pegawai kejaksaan & Proyek & 2020 & $\triangle$ Down \\
\hline
\end{tabular}

Gambar 15. Halaman Menu Katalog 


\subsubsection{Halaman Menu Buku Tamu}

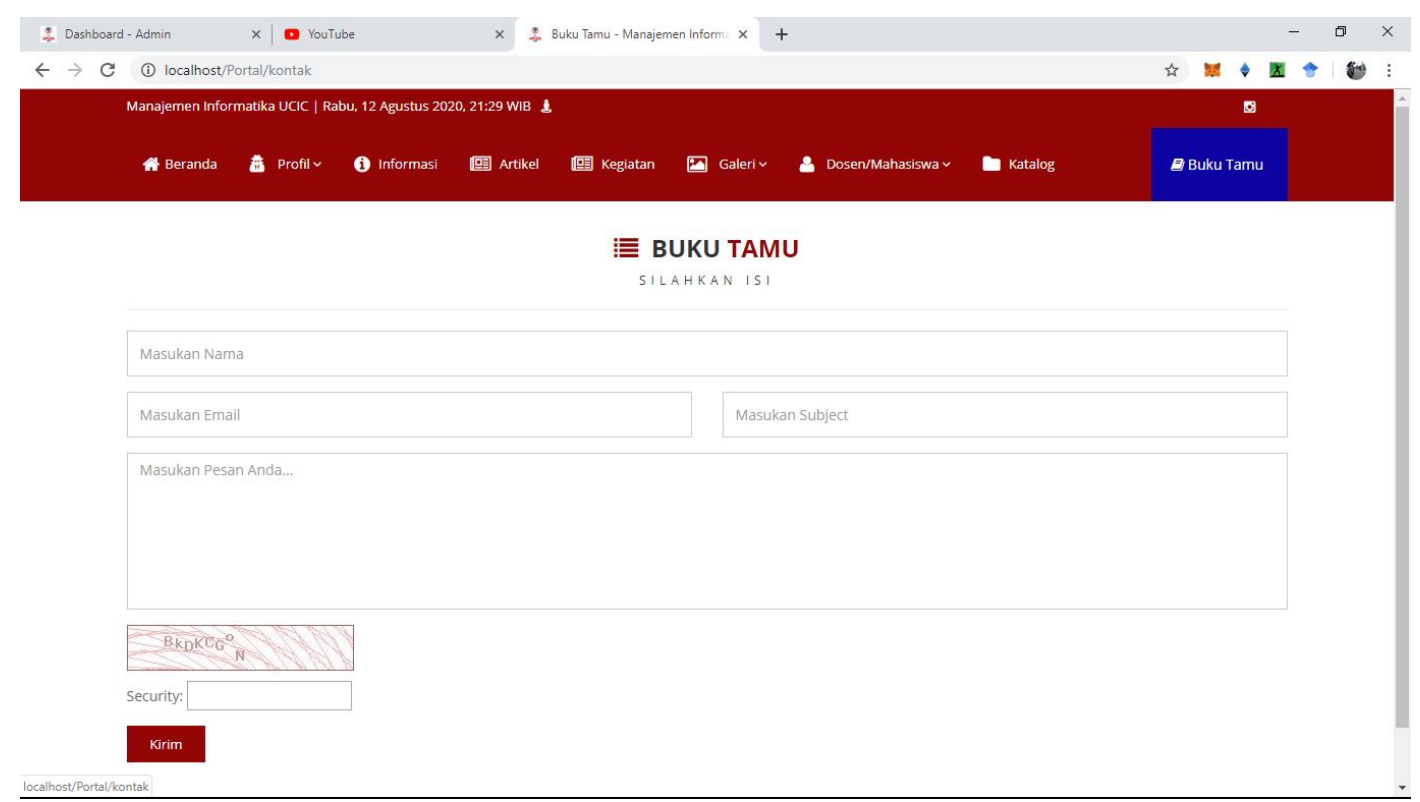

Gambar 16. Halaman Menu Buku Tamu

\section{KESIMPULAN DAN SARAN}

\subsection{Kesimpulan}

Berdasarkan penelitian di atas maka penulis membuat kesimpulan bahwa Aplikasi web portal manajemen informatika berbasis website dengan menggunakan framework codeigniter dan mysql dapat memberikan informasi kepada mahasiswa dan masyarakat menjadikan media promosi dan lain-lain. Web tersebut didalamnya mengelola data sebagai berikut:

1) Data Master (Data Dosen MI, Data Mahasiswa, Data Alumni MI, Data Buku Tamu, Data Artikel, Data Kegiatan, Data Agenda, Data Mahasiswa Berprestasi, Data Katalog, Data Informasi, Data Testimoni), Data Statistik, Data Media ( Data Galeri dan Data Video), Setting website (Kata sambutan, visi dan misi, Tujuan dan Kompetensi MI).

2) Mepermudah Mahasiswa Informatika dan Masyarakat mendapat Informasi dengan cepat.

\subsection{Saran}

Berdasarkan hasil keseluruhan penelitian yang telah dilakukan, maka penulis memberikan beberapa saran yaitu antara lain, untuk penelitian selanjutnya perancangan dapat menggunakan Sistem Framwework selain CodeIgniter seperti Laravel. Lumen, Symfony. Peneliti harap kedepannya sistem ini bisa online, di kembangkan lebih baik lagi dari sebelumnya.

Aplikasi Web Portal Manajemen Informatika Berbasis Website Dengan Menggunakan Framework Codeigniter Dan Mysql Pada Universitas Catur Insan Cendekia - (Wiwiek Nurkomala, Chairun Nas, 


\section{DAFTAR PUSTAKA}

Jurnal dan buku:

[1] Achmad Fikri Sallaby, Feri Hari Utami, Yode Arliando. Aplikasi Widget Berbasis Java. 2017 Penerbit : Jurnal Media Infotama ISSN :1858-2680.

[2] Achmad Solichin dan Bernadeta Asri Rejeki Tulodo. Analisis Pengaruh Kualitas Sistem, Kualitas Informasi dan Perceived Usefulness Terhadap Kepuasan Pengguna Aplikasi Care Dalam Upaya Peningkatan Kinerja Karyawan (Studi Kasus Pt. Malacca Trust Wuwungan Insurance, tbk.). 2019 Penerbit : Jurnal Riset Manajemen Sains Indonesia P-ISSN : 2087-1139 E-ISSN: 2301-8313.

[3] Annisa Paramitha F, S.Kom., M.Kom. Alat Bantu Analisis (Flowmap). 2019 Pen-erbit : repository.unikom.ac.id.

[4] Ario Suryo Kusumo. Administrasi SQL server 2014. 2016 Penerbit : PT Elex Me-dia Komputindo kelompok Gramedia,Anggota IKAPI, Jakarta 2016 ISSN :978-602-02-8494-1.

[5] Baiq Nonik Ria Riska, Bahtiar Imran, Erfan Wahyudi, Hasan Basri. Implementasi Website Portal Sekolah Sebagai Media Promosi dan Penyampaian Informasi (Studi Kasus : SMAN 1 Praya Timur). 2017 Penerbit : Jurnal Explore STMIK Mataram - Volume 7 No 2 Tahun 2017 ISSN:2087-894.

[6] Berkah Akbar Nuryaumil Aziz, Yoyok Heru Prasetyo, Mochammad Junus. Sistem Informasi Pengelolaan Surat Masuk dan Surat Keluar Jurusan Rlektro Politeknik Negeri Malang Berbasis Web Melalui Jaringan Intranet Polinema. 2019 Penerbit : JURNAL JARTEL Vol 9 No 2 JUNI 2019.

[7] Dahlan Abdullah. Merancang Aplikasi Perpustakaan menggunakan SDLC. 2017 Penerbit : Sefa Bumi Persada ISBN 978-602-6960-34-4.

[8] Elisabet Yunaeti Anggraeni dan Rita Irvian. Pengantar Sistem Informasi. 2017 Penerbit : CV.Andi Offset Isbn 978-979-29-6277-2.

[9] Fauzi Rahman, Santoso. Aplikasi Pemesanan Undangan Online. 2017 Penerbit :

[10] Fhery Agustin. Perancangan Web Portal pada Jaringan Intranet (study kasus : Stmik Potensi Utama). 2017Penerbit : e-journal.potensi-utama.ac.id. 